Revue bibliographique pour le domaine irano-aryen

\title{
Robā'ìyāt. Édité avec introduction par Akbar Behdārvand, Tehrān, Mo'assese-ye Entešārāt-e Negāh, 1385/2006, 663 p.
}

\section{Anna Livia Beelaert}

\section{(2) OpenEdition}

1 Journals

Édition électronique

URL : http://journals.openedition.org/abstractairanica/39779

DOI : 10.4000/abstractairanica.39779

ISSN : 1961-960X

Éditeur :

CNRS (UMR 7528 Mondes iraniens et indiens), Éditions de l'IFRI

\section{Édition imprimée}

Date de publication : 15 mai 2011

ISSN : 0240-8910

Référence électronique

Anna Livia Beelaert, «Robāîyāt. Édité avec introduction par Akbar Behdārvand, Tehrān, Mo'assese-ye Entešārāt-e Negāh, 1385/2006, 663 p. », Abstracta Iranica [En ligne], Volume 31 | 2011, document 275, mis en ligne le 11 octobre 2012, consulté le 04 octobre 2020. URL : http://journals.openedition.org/ abstractairanica/39779 ; DOI : https://doi.org/10.4000/abstractairanica.39779

Ce document a été généré automatiquement le 4 octobre 2020.

Tous droits réservés 
Robā‘ūyāt. Édité avec introduction par Akbar Behdārvand, Tehrān, Mo'assese-ye Entešārāt-e Negāh, 1385/2006, $663 \mathrm{p}$.

Anna Livia Beelaert 
Il semble que la nouvelle édition des œuvres complètes de Bīdel (1644-1721) qu'Akbar Behdārvand a commencée dans les années 1990, une trentaine d'années après celle que Halîl-Allāh Halīili prépara à Kabul, soit surtout inspirée par la difficulté de se procurer un exemplaire de cette dernière à l'heure actuelle. En effet, Behdārvand écrit lui-même (introduction p. 12-13 et p. 42) que l'édition présente des robāìyāt est seulement basée sur celle de Hualilì et une édition lithographe des Kollìyāt publiée à Bombay (on ne peut pas savoir laquelle, il n'en donne pas de date) ; il n'est pas question de manuscrits, bien que, comme le Fehrest-e nosHe-hā-ye Hațtî-ye färsī de A. Munzavi nous le montre, il en existe même quelques-uns écrits du vivant du poète ou peu après.

Bīdel fut un auteur prolifique, particulièrement de quatrains; il en écrivit, selon les sources, de 1861 jusqu'à plus de 4500 . Cette édition en compte 3842, mais elle n'est sûrement pas complète, puisque, par exemple, les œuvres en prose éditées séparément (c.r. ${ }^{\circ} 274$ ) en contiennent plusieurs qui ne sont pas inclus dans celle-ci. L'éditeur n'a ajouté aucune variante ou note, mais bien, inutilement, un "titre" à chaque quatrain, consistant en un mot - visiblement considéré comme mot-clé du poème (par exemple “ del", "hayrat"). Une édition critique et vraiment complète de toutes les œuvres de ce très grand poète reste donc toujours un desideratum.

3 Dans une assez décevante introduction (p. 9-41) l'éditeur essaie de placer ces quatrains dans un contexte littéraire en traitant sommairement l'histoire de ce genre, son usage par le soufisme et le "style indien" (sabk-e hendī). L'index alphabétique des premiers vers est à tort nommé "kašf al-abyāt" (p. 591-663).

Akbar Behdārvand

INDEX

Thèmes : 11.1.1. Littérature persane classique

\section{AUTEURS}

\section{ANNA LIVIA BEELAERT}

Université libre de Bruxelles 